\title{
Not OF Minor CONSEQUENCE?: MEDICAL DECISION-MAKING AUTONOMY AND THE MATURE MINOR DOCTRINE
}

\author{
Shawna Benston*
}

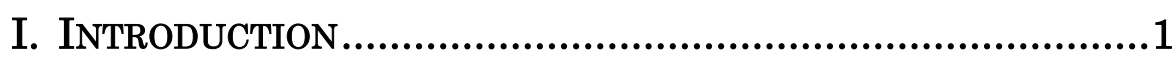

II. SubJeCtivity OF THE MATURE MinoR

DOCTRINE CRITERIA..............................................................

III. The MATURe Minor DoctRIne "At WORK” .....................8

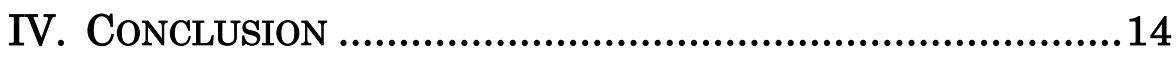

\section{INTRODUCTION}

The frequently intersecting notions of autonomy and capacity are often seen as divergent in cases of medical decision-making by children. The legal system grants autonomy to make medical decisions to those over the age of 18 and denies it to those under the age of 18 , due to an ostensible lack of "maturity" in the latter population sufficient to the legal authority to make such medical decisions. For those under the age of 18, their parents or legal guardians are called upon to formally dictate the direction of medical treatment; meanwhile, doctors and hospitals disagreeing with such parents' instructions can opt to bring the dispute to court. Thus, a child who might otherwise be able to engage, communicate, and participate in

* B.A., Yale University, J.D., Benjamin N. Cardozo School of Law, M.B.E., University of Pennsylvania, Postdoctoral Fellow in the Ethical, Legal and Social Implications (ELSI) of Genetics, Columbia University. This article was first presented at the Yale Interdisciplinary Center for Bioethics 2015 Summer Symposium. The author would like to express sincere gratitude to Steven J. Errante, Esq., for offering helpful suggestions. 
his medical decision-making might see his medical wishes overridden by others' potentially paternalistic choices.

However, the mature minor doctrine offers the chancein jurisdictions that recognize it-for minors to be deemed capable of making their own medical decisions. In order for minors to achieve this goal, they must satisfy various criteria predetermined by their respective states' common-law determinations. Having first emerged in the 1960s, notably in Smith v. Seibly, ${ }^{1}$ which in turn quoted from Grannum v. Berard, 2 the mature minor doctrine allows for some flexibility in a court's determination of who can influence and even guide the medical experience of the minor. However, the doctrine merely allows a recognizing court to consider whether a minor can be deemed mature. Furthermore, because of variations in jurisdictions' criteria for what constitutes "maturity" and the intrinsic subjectivity (as discussed below) of the criteria, rulings on mature minor petitions are minimally predictable. Therefore, the mature minor doctrine can lend predictability of process, as well as procedural justice, for minors wishing to challenge their medical teams' decisions, but the doctrine cannot guarantee predictability of outcome of such challenges.

In Smith v. Seibly, 431 P.2d 719, (Wash. 1967), Plaintiff argued that a medical procedure to which he consented at age 18-when the age of maturity in his state was, at the time, 21-was an assault and battery because true consent had not been given. The court found in favor of Defendant doctor, stating that the "[a]ppellant was married, independent of parental control and financial support and it was for the jury to decide if he was sufficiently intelligent, educated and knowledgeable to make a legally binding decision."

2 In Grannum v. Berard, 422 P.2d 812, 815 (Wash. 1967), Plaintiff claimed that his doctor committed common law battery by performing a procedure to which Plaintiff had consented as a minor. The court found for Defendant doctor. According to the court,

[i]n view of this record and the complete absence of medical testimony as to the plaintiff's claimed mental incapacity, we do not believe there is room for reasonable minds to differ that the plaintiff has failed to overcome by clear, cogent and convincing evidence the presumption that he comprehended the nature, terms and effect of the consent given for the surgical operation. 
This article explores the mature minor doctrine and how it has emerged in recent cases. It also discusses minors' generally limited autonomy and calls for those in the medical and legal professions to seriously contemplate what can be done to protect minors suffering from unwanted medical treatments-especially those that render life more painful and uncomfortable than happy and satisfying.

\section{SUBJECTIVITY OF THE MATURE Minor DoCtRINe CRITERIA}

At common law, minors are deemed incompetent to give consent or refuse medical intervention. It is therefore up to the individual states whether to evaluate a case under the mature minor doctrine, which considers legally relevant the desires, and consent or refusal, of minors who "exhibit[ the 'maturity' of an adult to make decisions that traditionally have been reserved for persons who have attained the age of majority." 3 Because "maturity' is not a well-defined legal term," 4 states that elect to conduct a mature minor doctrine analysis have determined sets of criteria that allow for casespecific determinations of a minor's maturity, or lack thereof.

Generally, as law professor Walter Wadlington has summarized, "the cases in which the rule has been applied have had the following factors in common" 5 :

(1) The treatment was undertaken for the benefit of the minor rather than a third party. (2) The particular minor was near majority (or at least in the range of 15 years of age upward) and was considered to have sufficient mental capacity to understand fully the nature and importance of the medical steps proposed.

3 Jessica A. Penkower, The Potential Right of Chronically III Adolescents to Refuse Life-Saving Medical Treatment Fatal Misuse of the Mature Minor Doctrine, 45 DePaUl L. REV. 1165, 1166 (1996).

4 Id. at 1167.

5 Id. at 1179. 
(3) The [risks of] medical procedures could be characterized by the court as less than 'major' or 'serious.' 6

The first factor necessarily specifies that any course of treatment or recommendation in question must be of potential benefit to the patient (patient-centered) and not primarily for the benefit of another party. In Belcher $v$. Charleston Area Medical Center, the Supreme Court of West Virginia exemplified how the second factor might be fully analyzed, explaining that whether a minor has sufficient capacity to consent to or refuse medical treatment depends upon:

[The] age, ability, experience, education, training, and degree of maturity or judgment obtained by the child, as well as upon the conduct and demeanor of the child at the time of the procedure or treatment . . . [and] whether the minor has the capacity to appreciate the nature, risks, and consequences of the medical procedure to be performed, or the treatment to be administered or withheld. ${ }^{7}$

Thus, for a proper analysis under the mature minor doctrine, the court must conduct an intensive investigation into who the minor is, what his life experiences have been prior to the hearing, and whether the minor has exhibited a sufficiently deep and thorough comprehension of his circumstances and treatment risks and benefits.

This type of tailored personal analysis lies in stark contrast to courts' medically inflected investigation of legal adults, who are presumed competent. The only potential roadblock to adults' medical decision-making authority—or

6 Id. at 1179-80 (drawing from Walter Wadlington, Minors and Health Care: The Age of Consent, 11 OsGoOd HALL L. J. 115, 119 (1973)).

7 Belcher v. Charleston Area Med. Ctr., 422 S.E.2d 827, 838 (W.Va. 1992). 
medical autonomy-is a collection of four countervailing state interests: "(1) the preservation of life, (2) the protection of innocent third parties, (3) the prevention of suicide, and (4) the maintenance of the ethical integrity of the medical profession."8

While adults can consent to medical treatment with extremely rare controversy ${ }^{9}$, the refusal of treatmentespecially when such refusal is guaranteed, or even just likely, to result in death-may come under scrutiny by institutional committees or governmental agencies, or may even be condemned in the court of public opinion. Most controversial, of course, is the decision by an adult to hasten death by means of physician-assisted suicide.

The case of Bouvia $v$. Superior Court epitomizes the difficulty that adults may encounter by seeking to remove or refuse life-saving medical intervention, or even hydration and nutrition. ${ }^{10}$ In this case the patient in question, Elizabeth Bouvia, was mentally competent but physically suffering from cerebral palsy, in anguish to the point of attempting suicide by means of self-starvation. After hospital staff forcibly inserted a nasogastric tube to keep her alive, Bouvia sought a preliminary injunction from the California trial court that would require the tube's removal and prohibit similar measures. After the trial court denied her preliminary injunction, she sought relief in the Court of Appeals of California. Citing the proclamation from the Council on Ethical and Judicial Affairs of the American Medical Association that "[a]t all times, the dignity of the patient should be maintained," 11 the Court of Appeals granted Bouvia the right to determine whether she would welcome or shun medical intervention. ${ }^{12}$ Ultimately, Bouvia

8 Penkower, supra note 3, at 1171.

9 A controversial treatment election might be extreme plastic surgery, for example.

10 Bouvia v. Superior Court, 179 Cal. App 3d 1127 (1986).

11 Id. at 1141 (quoting the Council on Ethical and Judicial Affairs of the American Medical Association, Withholding or Withdrawing Life Prolonging Medical Treatment (Mar. 15, 1986)).

12 Id. 
chose not to die by means of self-starvation, citing side effects of her morphine regimen that made starvation unbearable. ${ }^{13}$

Notably, the Bouvia court included discussion of two issues crucial to the exploration of the mature minor doctrine: (1) "[w]ho shall say what the minimum amount of available life must be?" 14 and (2) how can we reconcile the doctrine of double effect and the state's concern for preservation of life? The first issue is intrinsically philosophical and ostensibly rhetorical. But it should be answered quite simply with "no one." Realistically, no one can say when another person has lived long enoughwhether that other person is aged fifteen or ninety-five.

In the Bouvia case, Judge Beach illustrated a prioritization of quality over quantity:

Does it matter if it be 15 to 20 years, 15 to 20 months, or 15 to 20 days, if such life has been physically destroyed and its quality, dignity and purpose gone? As in all matters lines must be drawn at some point, somewhere, but that decision must ultimately belong to the one whose life is in issue. . . . It is not a medical decision for [the patient's] physicians to make.

13 See Jerry Menikoff, LAW AND Bioethics: An InTRoduction 262 (Georgetown University Press, 2001). During a 60 Minutes segment broadcast on September 7, 1997, the following dialogue took place:

Mike Wallace: (voiceover) 'After several attempt[s] at starvation, Elizabeth told us, it just became physically too difficult to do. She didn't want to die a slow, agonizing death, nor to do it in the spotlight of public scrutiny. And she told us, with great regret, she quietly chose to live.' Ms. Bouvia: 'Starvation is not an easy way to go.' Wallace: 'Oh, no.' Ms. Bouvia: 'You can't just keep doing it and keep doing it. It really messes up your body. And my body was already messed up.'

See also Beverly Beyette, The Reluctant Survivor: 9 Years after Helping her Fight for the Right to Die, Elizabeth Bouvia's Lawyer and Confidante Killed Himself-Leaving Her Shaken and Living the Life She Dreaded, LA Times (Sept. 27, 1992), http://articles.latimes.com/1992-0913/news/vw-1154_1_elizabeth-bouvia [http://perma.cc/MTJ2-5QZZ].

14 Bouvia, 179 Cal. App 3d 1127 at 1143. 
Neither is it a legal question whose soundness is to be resolved by lawyers or judges. It is not a conditional right subject to approval by ethics committees or courts of law. It is a moral and philosophical decision that, being a competent adult, is [the patient's] alone. ${ }^{15}$

Of course, the Bouvia court was examining an issue of adult competence to make medical decisions; what remains to be explored is whether a capacitated minor can be granted the same freedom to determine for himself how much life devoid of "quality, dignity and purpose" is enough.

The doctrine of double effect "is often invoked to explain the permissibility of an action that causes a serious harm, such as the death of a human being, as a side effect of promoting some good end." 16 Specifically, the doctrine of double effect states that "if doing something morally good has a morally bad side effect," it is ethical to do it as long as the bad side effect was not intended-and even if the bad effect was foreseen as probable. ${ }^{17}$ The principle is used to justify a doctor's giving drugs to a terminally ill patient to relieve distressing symptoms even though he knows that doing so may shorten the patient's life. An analysis under this doctrine must examine the "fundamental legal principles of causation and intent" 18 in its determination that a patient's refusal of medical intervention, or consent to aggressive palliative care, results in death from the underlying disease or pathology - not from the withholding of medical care or application of palliative care. ${ }^{19}$

15 Id.

16 Alison McIntyre, Doctrine of Double Effect, STANFORD ENCYCLOPEDIA OF PHILOSOPHY (Sept. 13, 2014),http://plato.stanford.edu/ entries/double-effect/ [http://perma.cc/B3WU-ZY8T].

17 See, e.g., Ethics Guide: The Doctrine of Double Effect, BBC, http://www.bbc.co.uk/ethics/euthanasia/overview/doubleeffect.shtml [http://perma.cc/H2ZD-5SZT] (last visited Oct. 2, 2015).

18 Vacco v. Quill, 521 U.S. 793, 801 (1997).

19 Id. at 801-02 (quoting Assisted Suicide in the United States, Hearing before the Subcommittee on the Constitution of the House Committee on the Judiciary, 104 ${ }^{\text {th }}$ Cong. 2d Sess., 367 (1996)). 
Such an arguably passive death notably differs from an active death achieved by assisted suicide. It is this distinction between "letting die" and "killing" that underlies many of the arguments against assisted suicide; 20 for purposes of this article, it should be understood as a point of clarity for informed consent cases involving adults: While a competent adult cannot, in most states, legally consent to assisted suicide measures to hasten death, generally (thanks to cases like Bouvia), he can refuse life-saving medical intervention, even if it results in his death. This article asks: can mature minors be granted the same sort of autonomy by means of a mature-minor-doctrine analysis, and, if so, why aren't more states conducting mature-minor-doctrine analyses?

\section{The MATURe MinOR DOCTRINE “At WORK”}

To illustrate a court's investigative process under the mature minor doctrine, we turn now to Cassandra C., a 17year-old Connecticut patient with Hodgkin's lymphoma, whose case provides what might have been deemed an easy one for an application of the mature minor doctrine, even while a mature-minor determination proved impossible. ${ }^{21}$ Since her diagnosis in September 2014, Cassandra has asserted her desire not to receive chemotherapy as treatment for her cancer, even though patients with her diagnosis are considered by the oncologic community to have an $80 \%$ chance of long-term survival with early treatment. ${ }^{22}$ Condemning the chemotherapy as "poison," Cassandra has apparently believed for many years prior to her diagnosis

20 Shawna Benston, Balancing Autonomy and Beneficence: The Legal, Sociopolitical, and Philosophical History of and Support For Legalizing Assisted Suicide, 24 NYSBA ELDER \& SPECIAL NEEDS L. J., 22, 22-28 (2014).

21 In Re Cassandra C., 316 Conn. 476 (2015).

22 Samantha Masunaga, "Connecticut Teen Fighting State Justices' Ruling on Forced Chemotherapy", L. A. TiMEs (Jan. 10, 2015, 8:53 PM), available at http://www.latimes.com/nation/la-na-teen-chemo-20150111story.html [https://perma.cc/B9M8-G44V]. 
that such treatment would be intolerable to her-in other words, her antipathy was not casually or swiftly determined. 23 Furthermore, not only was Cassandra less than a year away from legal maturity at the time of her case, but her mother fully agreed with and supported her desire to abstain from chemotherapy, despite the potentially dire consequences. ${ }^{24}$

However, after Cassandra and her mother missed some of her medical appointments, "her physicians made a report of possible medical neglect to the Petitioner, Department of Children and Families ('DCF')," 25 which in turn filed a petition for and won an Order of Temporary Custody. ${ }^{26}$ A sixmonth regimen of chemotherapy was begun. Soon thereafter, the Supreme Court of Connecticut affirmed that the state could force a minor to undergo chemotherapy. ${ }^{27}$ So, had that court conducted an analysis under the mature minor doctrine?

Yes and no: The Supreme Court of Connecticut stated in its opinion that "because the evidence does not support a finding that Cassandra was a mature minor under any standard, this is not a proper case in which to decide whether to adopt the mature minor doctrine." 28

However, certainly it is at least a bit nonsensical to say that a doctrine is not being adopted because the case at hand does not satisfy it. In effect, the court did conduct a matureminor-doctrine analysis, finding that Cassandra did not satisfy the criteria. Thus, Cassandra's case constitutes the first in which the Connecticut Supreme Court considered the mature minor doctrine, setting a precedent that justifiably dismays Cassandra. Indeed, as the American Civil Liberties Union of Connecticut reminded the court in its amicus brief,

3 Id. at 492.

$24 \mathrm{Id}$.

25 Joint Brief of Respondent Mother and Minor Child with Separate Index at 1-2, In re Cassandra C., 316 Conn. 476 (2015).

26 In re Cassandra C., 316 Conn. 476, 486 (2015).

27 Id. at 500.

28 Id. at 481. 
prior to the court's decision Texas had been the only state to reject the mature minor doctrine, while six other states and Washington, D.C. "have held or suggested that mature minors, like other competent people, have the right to consent to or forego medical treatment. ${ }^{29}$

The court, however, found persuasive the argument of DCF's counsel, Assistant State Attorney General John Tucker, that Cassandra and her mother had engaged in "magical thinking' that '[i]f I closed my eyes to the fact I have this serious illness, then my cancer doesn't exist."'30 Tucker further asserted that "[r]eally, it was the mother who was taking the front seat on this. The child was overshadowed by the mother's negative feelings about chemotherapy." 31 However, Cassandra herself defended her mother in an oped, stating, "In no way is my mom neglectful. She has always put me before herself. I am offended by anyone who believes otherwise. My mom has been identified as 'hostile,' 'neglectful' and 'unsupportive,' three untrue words that break my heart." 32

Furthermore, Cassandra's op-ed expressed her firm understanding that her desired abstention from chemotherapy was driven by her own feelings and beliefs

29 Christiane Cordero, State Supreme Court Rules Teen Canate Supreme Cou., NBC ConnecticuT (Jan. 8, 2015, 12:12 PM), http://www.nbcconnecticut.com/troubleshooters/State-Supreme-CourtHears-Arguments-in-Teen-Chemotherapy-Case-Cassandra-Connecticut287933331.html [http://perma.cc/TWE7-F7B3]. These six states are "Illinois, Maine, Tennessee, West Virginia, Michigan, and Massachusetts."

30 Josh Kovner, Connecticut Supreme Court Upholds Ruling That State Can Force Chemotherapy On Teen, HARTFORD CouRANT, (Jan. 8, 2015, 9:14 PM), http://www.courant.com/news/connecticut/hc-teenbattles-chemo-order-0103-20150102-story.html\#page $=1$ [http://perma.cc/ $4 \mathrm{HQL}-4 \mathrm{~B} 3 \mathrm{~J}]$.

31 Id.

32 Cassandra C., Op-Ed. Cassandra's Chemo Fight: 'This Is My Life And My Body', HARTFORD COURANT, (Jan. 8, 2015), http://www.courant.com/opinion/op-ed/hc-op-cassandra-my-body-my-life0109-20150108-story.html?dssReturn\&z=10003 [http://perma.cc/DL6V$6 \mathrm{JDH}]$. 
about what would be right for her. Her fear and frustration are unequivocal:

This experience has been a continuous nightmare. I want the right to make my medical decisions. It's disgusting that I'm fighting for a right that I and anyone in my situation should already have. This is my life and my body, not DCF's and not the state's. I am a human-I should be able to decide if I do or don't want chemotherapy. Whether I live 17 years or 100 years should not be anyone's choice but mine. How long is a person actually supposed to live, and why? Who determines that? I care about the quality of my life, not just the quantity. ${ }^{33}$

Bouvia is loudly echoed in this statement, which certainly exhibits the level of maturity required for a judge's ruling that the speaker should be permitted to make her own medical decisions. And yet, Cassandra was forced to continue being injected with what she deemed "poison." 34 What went wrong?

In the Supreme Court of Connecticut's ruling, it appears that the finding that Cassandra was not a mature minor was based on her having either intentionally misrepresented her intentions to the trial court or ... changed her mind on this issue of life and death [and that] [i]n either case, her conduct amply supports Judge Quinn's finding that the respondents

33 Id.

34 Sarah Larimer, Connecticut's Highest Court Approves Forced Chemotherapy for Teen, THE WAshington Post (Jan. 8, 2015), http://www.washingtonpost.com/news/morningmix/wp/2015/01/08/ connecticuts-highest-court-approves-forced-chemotherapy-for-teen/ [http://perma.cc/6RRJ-3SYL]. 
[Cassandra and her mother] have failed to prove that Cassandra was a mature minor under any standard. ${ }^{35}$

The court essentially found it more reprehensible that Cassandra had temporarily run away, in order to avoid being medicated against her will, than that she had been "strapped to a bed by [her] wrists and ankles and sedated" 36 and might be again. Because the court found issue with Cassandra's potentially having changed her mind, it can be inferred that in order to make medical decisions, one must never change one's mind. So, should Elizabeth Bouvia have been retroactively found incompetent after she chose to keep on living?

Of course, the answer should be "no." The law does not say that in order to be one's own medical decision-maker, one must be bound to the first opinion or decision one makes, but that in order to make legally valid medical decisions, one must be able to provide competent and informed consent or refusal of medical care. It is common knowledge that throughout a course of treatment—especially for an ongoing and potentially dire condition-a patient might change direction, especially as new or changed information becomes available. It would be unethical to force a patient to stick with his first opinion or decision, in a contract-like arrangement; by extension, it should be unethical to do the same to a minor who would otherwise be deemed mature. And yet, Cassandra was effectively punished for her having even just potentially changed her mind about life's perhaps most confusing issue: what constitutes a life worth living?

It is worth asking whether the judge's ruling would have been different had Cassandra presented a religious basis for her wish to withdraw and withhold medical intervention. The critical mature-minor-doctrine case, In re E.G., found a minor the same age as Cassandra—seventeen-competent to refuse a blood transfusion as part of treatment for leukemia.

35 Order at 2, In re Cassandra C., 112 A.3d 158 (Conn. 2015) (No. 19426), available at http://www.scribd.com/doc/252076272/Cassandra [https://perma.cc/A3WC-2ZWM].

36 Cassandra C., supra note 32. 
The basis for this competence was that "acceptance of blood would violate personal religious convictions rooted in [E.G.'s] membership in the Jehovah's Witness faith." 37 Although the court did not base its decision on religious grounds, the religious conviction of the minor is what garnered her sufficient recognition to allow for the court's mature-minor analysis. Specifically, the court compared the E.G. case to two previous cases ${ }^{38}$ that involved Jehovah's witnesses, allowing for consideration ${ }^{39}$ of E.G.'s case despite its having been rendered moot due to E.G.'s having reached the age of majority.

Although E.G. and her mother provided a constitutional basis - the First Amendment's Free Exercise Clause-for the refusal of the blood transfusion, the judge declined to consider it, saying that "a mature minor may exercise a common law right to consent to or refuse medical care." 40 The judge thereby strengthened the mature minor doctrine by finding it sufficient in itself, without constitutional support, to allow a mature minor to refuse life-saving treatment. Indeed, the E.G. court did not wish to find or make an extension of the constitutional right of abortion, which naturally is granted to minors because "[c]onstitutional rights do not mature and come into being magically only when one attains the state-defined age of majority." 41 Thus, it was a rather strange case: while religious reasoning, built on a Free Exercise Clause foundation, helped convince the judge of E.G.'s maturity (in other words, it got E.G.'s foot in the door), a constitutional analysis was found irrelevant. A pivotal statement made in the opinion — " "[w]e see no reason

37 In re E.G., 549 N.E.2d 322, 323 (Ill. 1989).

38 The two cases were In re Estate of Brooks, 205 N.E 2d 435 (Ill. 1965) and People ex rel. Wallace v. Labrenz, 104 N.E. 2d. 769 (Ill. 1952).

39 The court found a public interest exception to mootness because of the frequency of cases involving Jehovah's Witnesses members who refused to consent to blood transfusions. In re E.G., 549 N.E.2d 322 at 325 .

40 In re E.G., 549 N.E.2d 322 at 328.

41 Id. at 326, quoting Planned Parenthood v. Danforth, 428 U.S. 52, 74 (1976). 
why this right of dominion over one's own person should not extend to mature minors" 42 - highlights the importance of the finding of maturity, while underscoring that once a minor is found mature, control over his person should be treated as a right.

If proof of a minor's maturity is his religious conviction if a minor's religious conviction is considered proof that the minor should be taken seriously - what hope do irreligious minors have of proving themselves competent to make their own medical decisions? While one commentator has found that "[t]he disparity among jurisdictions in their use of the [mature minor] doctrine, the inherent vagueness of the concept of maturity, and the complexity of the medical and legal matters involved in treatment refusal cases effectively undermine the doctrine's efficacy," 43 it seems that such vagueness could work as easily for minors as against them. Just as not all adults are competent to make their own medical decisions, so, too, are not all minors lacking in the maturity required to do so. There should not be-and, in practice, is not - a bright line dividing adults and minors that, on the former side, includes all competent individuals and, on the latter side, includes all incompetent individuals. A more nuanced analysis is required on a case-by-case basis to determine an individual's medical-decision-making competence, regardless of that individual's age.

\section{CONCLUSION}

When are young people old enough to make potentially life or death decisions? We allow 17-year-olds to enlist in the army. Teens as young as 15 are regularly tried as adults in murder cases. So why shouldn't a 17-year-old have the right to decide what medical treatments she will undergo? ${ }^{44}$

42 Id. at 326.

43 Penkower, supra note 3 , at 1191.

44 W.W., Cassandra's Catch-22, The Economist (Jan. 14, 2015, 2:57 PM), http://www.economist.com/blogs/democracyinamerica/2015/01/ medical-consent [http://perma.cc/97BG-GRNK]. 
We can easily see divergences in how the law and society view and treat minors, and such divergences have had a notable impact on minors' ability to make their own medical decisions. Indeed, perhaps it is this lack of predictability that particularly harms minors and even their parents, who might - as in Cassandra's case ${ }^{45}$ — support their children's desire to withhold or withdraw medical intervention.

However, the solution is not to insert predictability by drawing a bright line at age 18 for purposes of bodily autonomy. Instead, the mature minor doctrine should be employed to make an informed, nuanced analysis of each case. Parental accord with children's wishes should only strengthen a case for finding a minor mature, instead of being ignored simply because such accord does not comport with the medical team's recommendations. States that employ the mature minor doctrine do right to weigh the state interests of "(1) preserving life; (2) protecting third parties;

(3) preventing suicide; and (4) maintaining the ethical integrity of the medical profession" against "the strength of the minor's right to refuse treatment." 46 Allowing for a caseby-case analysis is appropriate, considering that no individual-and no minor individual_-is the same as any other; one person's medical experiences and personal traits are not necessarily replicated in another's.

Indeed, perhaps the solution lies outside the courtroom setting and should be determined as part of the doctorpatient interaction and with as much concern for a minor's informed consent as for that of an adult patient. Or, should this discussion remain in the courtroom, perhaps a shift of the burden of proof is in order: a minor in his mid-teens should be presumed competent unless proven otherwise.

45 Id. ("as it happens, Cassandra's mother, Jackie Fortin, supports her daughter's decision to forgo chemotherapy treatments. Is Cassandra's middle-aged mother too immature to make decisions on her daughter's behalf? Presumably not. So what gives?") While the Connecticut Supreme Court ultimately found Cassandra's mother neglectful, certainly such a finding would not in itself override a finding that a minor is sufficiently mature to justify recognition of her own medical decision-making capacity.

46 Penkower, supra note 3, at 1187 (citing In re E.G., 549 N.E.2d 322, 328 (Ill. 1989)). 
Ultimately, it must be determined what, exactly, "mature" means, both literally and legally. Who determines when another person has become "mature"? What role does, and should, age play in determining someone's "maturity"? How can our legal system grapple with such nebulous terminology? Finally, how can physicians work within the legal system while upholding their oath to do no harm?

As we continue wrestling with such questions, courts would do well to employ the mature minor doctrine in order to lend predictability of process to cases of minors' bodily autonomy, while preserving the states' interests. In this way, analysis using the mature minor doctrine would allow courts to protect immature minors from potentially detrimental medical decisions, which they lack the capacity to make, while honoring mature minors' informed and competent medical decision-making capacity. Such analysis would also provide procedural justice for minors, even if the result is not in their favor. 47

It is not the age of 18 that should signify maturity and the competence to manage one's own medical treatment, but rather the confluence of emotional maturation, sufficient experience and education, and developed judgment and demeanor at the time of the potential treatment that must be analyzed to determine a minor's capacity to refuse unwanted medical intervention. The legal system, if it is to adequately protect minors, must consider the minor's potential to make well-informed medical decisions.

47 Nancy Welsh, Making Deals in Court-Connected Mediation: What's Justice Got to Do With It? 79 WASH. U. L.Q. 787, 820 (2001). 